\title{
IMPLEMENTASI KONSELING KELOMPOK UNTUK MENGATASI PRAKTIK BULLYING
}

\author{
Azhari \\ Universitas Islam Negeri (UIN) Ar Raniry Banda Aceh \\ e-mail: abankazhari@ymail.com
}

\begin{abstract}
This study aims to see the implementation of group counseling as an effort to solve the problem of bullying on students through field research. In it the researcher tries to decipher the view of thinking which emphasizes the focus of subjective experience through observations, including interview texts, field notes, photos, memos, and other documents, using Miles and Huberman analysis such as data reduction (data reduction), data display (data present) and and verification of data (conclusions). Field results show that the completion of bullying practices through group counseling is packaged in four sessions, namely: Session I group formation. The transition II session aims to provide feedback, emotional closeness between students and counselors and the process of identifying problems faced by students. The third session of the activity contained a material model, including: a group counseling model based on a persuasive approach, a group counseling model based on a classical approach, a social approach based counseling model, a group counseling model based on an Islamic approach. Closing session IV. The general aim of group counseling implementation is to restore the relationship of negative thoughts and feelings to the relationship of positive thoughts and feelings in shaping new behaviors so that when faced with problems, students are able to find positive alternatives in achieving solutions. Constraints faced include internal student constraints and the internal constraints of the counselor.
\end{abstract}

Key Words: Group Counseling, Bullying

Abstrak. Penelitian ini bertujuan untuk melihat implementasi konseling kelompok sebagai upaya penyelesaian masalahan bullying pada siswa melalui penelitian lapangan (field research). Di dalamnya peneliti mencoba menguraikan pandangan berpikir yang menekankan pada fokus pengalaman subjektif melalui observasi terdapat naskah wawancara, catatan lapangan, foto, memo, dan dokumen lainnya, dengan menggunakan analisis Miles dan Huberman seperti reduction data (reduksi data), display data (penyajian data) dan verifikasi data (kesimpulan). Hasil lapangan menunjukkan bahwa penyelesaian praktik bullying melalui konseling kelompok dikemas dalam empat sesi yaitu: Sesi I pembentukan kelompok. Sesi II peralihan, bertujuan agar terjadi umpan balik, kedekatan emosional antara peserta didik dengan konselor serta proses identifikasi masalah yang dihadapi peserta didik. Sesi III kegiatan berisi model materi diantaranya: model konseling kelompok berbasis pendekatan persuasif, model konseling kelompok berbasis pendekatan klasikal, model konseling berbasis pendekatan sosial, model konseling kelompok berbasis pendekatan Islam. Sesi IV penutup. Tujuan secara umum implementasi konseling kelompok untuk mengembalikan hubungan pikiran dan perasaan yang negatif kepada hubungan pikiran dan perasaan yang positif dalam membentuk prilaku baru sehingga ketika selanjutnya berhadapan dengan masalah, peserta didik mampu menemukan alternatif-alternatif positif dalam pencapaian jalan keluar. Kendala yang dihadapi diantaranya kendala internal peserta didik dan kendala internal konselor.

Kata Kunci: Konseling Kelompok, Bullying 


\section{PENDAHULUAN}

Keberadaan esensi pendidikan dewasa ini kembali dipertanyakan dan mendapat guguatan oleh berbagai pihak (Wiyani, 2013). Berangkat dari kasus-kasus yang menyelimuti dunia pendidikan seperti yang terjadi pada ER, peserta didik kelas II salah satu SD di Jakarta Timur. Korban meninggal dunia setelah dihakimi empat teman sebayanya di sekolah. ER sering mendapat perlakuan tidak adil dan menjadi sasaran rutin untuk disiksa (Harian Kompas 28 April 2008). Selanjutnya duka kembali menyelimuti dunia pendidikan atas meninggalnya tiga mahasiswa di salah satu Universitas terkemuka di Yogyakarta dalam pelaksanaan diksar Mapala kampus tersebut. Kasus ini juga berangkat dari budaya perpeloncoan dalam menyambut mahasiswa baru setiap tahun diseluruh Universitas yang ada di Indonesia (SINDONEWS 30 Januari 2017).

Sekolah merupakan tempat pengembangan potensi inti secara formal dan juga menjadi tempat potensial malpraktik dan stresor yang dapat mengganggu peserta didik baik secara biologis atau psikologis. Barbara Krahe menyebutkan unsur di dalamnya memarahi, menghina, memukul, menampar dan sebagainya disebut dengan perilaku bullying (Jamal, 2016). Wiyani (2013) mengatakan bullying adalah prilaku agresif dan negatif seseorang atau sekelompok orang secara berulang kali meluapkan kekuatan bukan pada tempatnya sehingga dapat menyakiti targetnya (korban) secara mental atau secara fisik. Stresor yang kerap terjadi dalam pendidikan formal adalah perilaku bullying di sekolah (school bullying). Dampak jangka panjang yang akan terjadi perkelahian, intimidasi antar peserta didik, pelecehan, hilangnya rasa percaya diri, Pembunuhan. Akhir dari cerita rusaknya generasi bangsa Indonesia jika permasalahan tersebut tidak diselesaikan. Dalam prinsip pendidikan nasional yang dituangkan dalam peraturan menteri pendidikan nasional RI. No. 41 tahun 2007, salah satu prinsip pendidikan adalah diselenggarakan sebagai proses untuk merintis, membudayakan dan pemberdayaan peserta didik generasi bangsa Indonesia. Dalam prosesnya diperlukan pengajar yang memberi keteladanan, mendongkrak motivasi, potensi, dan kreativitas peserta didik.

Merujuk pada undang-undang tersebut, bimbingan dan konseling merupakan layanan bantuan untuk menyikapi permasalahan dalam lingkungan pendidikan formal dan nonformal. Salah satunya dengan menggunakan pendekatan konseling kelompok. Konseling kelompok adalah cara alternatif kekinian sekolah dalam mengatasi permasalahan yang ada dan sebagai serangkaian kegiatan pokok dari bimbingan dan konseling (BK) untuk membantu peserta didik atau konseli/klien secara tatap muka dengan tujuan agar konseli dapat mengambil tanggung 
jawab sendiri terhadap persoalan yang sedang dihadapi (Febriani, 2011). Dari keterangan Juntika (2006) konseling kelompok adalah media penyampaian informasi yang aktifitasnya didominasi untuk membahas masalah-masalah pendidikan, pekerjaan, pribadi dan sosial. Masih dalam ruang tersebut, Prayitno mengemukakan bimbingan kelompok di sekolah merupakan upaya positif yang kandungannya terdapat informasi sebagai upaya membantu menyusun rencana dan keputusan yang tepat. Gazda dalam Prayitno (2014) juga menafsirkan bimbingan kelompok adalah upaya konselor memberikan informasi yang bersifat personal, vokasional, dan sosial.

Sekolah Dasar Islam Terpadu (SDIT) Luqman Al-Hakim yang beralamat Jl Timoho Gg 2 Delima No 2 Muja-muju Umbulharjo Yogyakarta adalah salah satu sekolah yang sudah menerapkan sistem pembelajaran yang berkelompok melalui konseling kelompok. Langkah awal sebelum proses konseling kelompok dilaksanakan menentukan homogenitas permasalahan, waktu pelaksanaan, komitmen peserta sebagai bentuk kepastian, kemampuan konselor yaitu kemampuan pedagogik, kemampuan sosial, kemampuan religius, inovasi, kemampuan menguasai teknik seperti attending, empati, refleksi, eksplorasi, menangkap pesan utama, open question, closed question, memimpin dinamika grup, menjernihkan, memudahkan, mengambil inisiatif, memberi nasehat, memberi informasi, merencanakan dan menyimpulkan (Lubis, 2011).

Namun pada kenyataannya proses yang dilewati pasca konseling kelompok tidak selalu berjalan searah dengan potensi, harapan, linier dengan nilai-nilai yang dianut. Peserta didik pasca menjalani konseling kelompok bertolak belakang dengan hasil yang diharapkan. Berangkat dari data yang tercatat pada tahun 2016 ada 10 kasus praktik bullying serta 6 kasus pada bulan Januari hingga Mei tahun 2017 yang terjadi di SDIT Luqman Al-Hakim Yogyakarta. Dalam statusnya SDIT sebagai sekolah Islam Terpadu, kasus tersebut digolongkan serius dan bertentangan dengan visi dan misi sekolah SDIT yang Islami. Kasus tersebut mengambarkan bahwa peserta didik tidak ada kekebalan fisik dan mental terhadap lingkungan sekitar pasca konseling kelompok, di mana hasil dari konseling kelompok tidak melekat dalam jiwa peserta didik seiring melewati kehidupan sehari-hari baik di rumah atau di sekolah.

\section{METODE}

Pendekatan penelitian yang digunakan yakni kualitatif. Subyek penelitian ini diantaranya adalah konselor sekolah, peserta didik yang terlibat kasus bullying di sekolah serta 
data-data terkait sebagai dukungan dalam proses investigasi bullying di sekolah. Konselor secara rutin berperan langsung dalam menyikapi permasalahan bullying dan peserta didik yang terlibat dalam kasus bullying hingga terbentuknya konseling kelompok. Metode pengumpulan data dalam pencapaian relevansi yang akurat melalui teknik-teknik telaah dokumen, observasi dan wawancara. Sedangkan metode analisis data, dengan metode analisis sebelum memasuki lapangan (Sugiyono, 2013) dan analisis data di lapangan dengan prosedur pendekatan Miles dan Huberman dengan awalan reduction data (reduksi data), display data (penyajian data) dengan membuat rangkuman temuan secara sistematis (Nazir, 2003), serta verifikasi data (kesimpulan) yang kredibel (Sugiyono, 2013).

\section{HASIL DAN PEMBAHASAN}

Hasil temuan penelitian menunjukkan bahwa implementasi konseling kelompok dalam mengatasi praktik bullying di SDIT Lukman Al-Hakim Yogyakarta dikemas dan dilewati dengan beberapa tahapan diantaranya:

1. Tahap Prakonseling

Konselor Muhammad Hermawan menjelaskan ada dua pertimbangan yang harus dilihat oleh konselor dalam memperjelas pokok permasalahan. Pertama melihat daftar permasalahan kasus bullying atau daftar cek masalah, selanjutnya melihat riwayat keluarga konseli. Pertimbangan ini dilakukan untuk memperjelas pokok permasalahan yang mengacu pada penyikapan yang optimal serta mengacu pada homogenitas permasalahan.

2. Tahap Pelaksanaan

Dalam istilah SDIT Luqman Al-Hakim, tahapan tersebut lebih dikenal dengan sesi konseling. Dalam sesi ini bersamaan dengan tahapan yang dikemukakan oleh Prayitno. Sesi tersebut antara lain:

a. Sesi I (Pembentukan)

Pada sesi ini konselor terfokus pada pengembangan informasi kelompok guna memotivasi konseli dengan agenda yang akan dijalankan dalam kelompok. Didalamnya membahas aturan-aturan, kode etik dengan pola komunikasi menggunakan pola pendekatan anak-anak dikarnakan peserta yang terlibat dari kalangan anak yang berusia 9 sampai 12 tahun. 
b. Sesi II (Peralihan)

Dalam sesi peralihan adanya transferensi permasalahan yang di limpahkan anggota kelompok. Didalamnya terkait pengalaman masa konseli hingga terjadinya bullying. Secara khusus peneliti melihat konselor menunjukkan sikap kedewasaan, profesional dan pengaruhnya pada konseli melalui interaksi positif yang menggambarkan kedekatan emosional antara konseli dengan konselor. Pola yang dibangun dalam dinamika kelompok, adanya umpan balik (feedback) dan tanya jawab serta saling memberi perhatian satu sama lain.

Selanjutnya dalam sesi peralihan, Ada beberapa faktor yang melatar-belakangi konseli berbuat bullying diantaranya faktor internal berhubungan dengan rendahnya harga diri, merasa diasingkan, kurangnya kecakapan dalam berinteraksi hingga timbul kesalahpahaman dengan kelompok teman sebaya dan mendorong konseli untuk berbuat prilaku bullying untuk menunjukkan pengakuan keberadaannya dan pencapaian kepuasan. Faktor eksternal diantaranya: faktor teman sebaya yang sensitivitas, faktor broken home seperti pertengkaran orang tua secara lisan dan fisik yang dilihat oleh anak, faktor sekolah yang memberi dampak negatif seperti banyak tugas yang diberikan, akibatnya peserta didik stres hingga ada rasa ketakutan akan kegagalan.

Peneliti menemukan bentuk-bentuk bullying yang lazim terjadi diantaranya: Flaming (terbakar): membuat amarah orang lain dengan kata-kata. Harassment (gangguan) berupa menyembuyikan barang orang lain. Denigration (pencemaran nama baik) mempermalukan seseorang dengan cara membuka aib bertujuan merusak reputasi dan nama baik target. secara langsung korban dan pelaku bullying mencoba merespon diantaranya: reaksi bertahan (defence reaction) dengan cara menyesuaikan diri, menyimpan semua emosi negatif dan positif di dalam hati, tujuannya konseli mampu membentuk security self untuk dapat membatasi benturan-benturan yang mengarah pada dirinya. Reaksi menyerang (aggressive reaction) dapat dikelompokkan bullying fisik. Dalam sesi peralihan ini konselor lebih banyak mendengarkan apa yang disampaikan peserta dan mengoptimalkan teknik-teknik konseling dalam menjalani dinamika konseling kelompok.

\section{c. Sesi III (Kegiatan)}

Dalam sesi ketiga adalah sesi lanjutan dari sesi kedua, Dari hasil pengamatan dan wawancara, konselor lebih mengisi model materi-materi: (1) model konseling kelompok berbasis pendekatan persuasif, model ini, konselor lebih menekankan pada aspek kognitif, sikap dan prilaku. Tujuannya agar konseli bertindak sesuai dengan harapan. (2) model 
konseling kelompok berbasis pendekatan klasikal, dilaksanakan melalui interaksi edukatif, menggunakan metode ceramah, diskusi, tanya jawab, LCD, media film, hand out, papan tulis, dan terjadual. Topik yang diangkat antara lain, cerita motivasi, tugas, tanggung jawab dan kasih sayang serta trening motivasi dengan durasi waktu hanya 30 menit sampai 1 jam. Upaya ini dilakukan sebagai bentuk percontohan, membuka wawasan, mendapatkan pengalaman dan pemahaman dalam memancing motivasi, percaya diri, dan kasih sayang antar sesama. (3) model konseling kelompok berbasis pendekatan sosial, dengan melihat nilai-nilai interaksi positif hingga terjadi transferensi dimana anggota kelompok melimpahkan pengalaman masa lalunya kepada konselor dan konselor memperhatikan apa yang disampaikan oleh konseli. (4) model konseling kelompok berbasis pendekatan religius, tujuan umum tersebut agar memiliki aqidah, benar sesuai dengan Islam, taqwa kepada Allah SWT, melakukan ibadah yang benar, memiliki akhlak yang matang dan terpuji dengan cara menampilkan perilaku yang santun, tertib, disiplin, peduli, sabar, ulet, pemberani dalam menghadapi permasalahan hidup sehari-hari, memiliki kemandirian, memiliki wawasan berpikir yang luas kritis, logis, sistematis, kreatif, cermat, cerdik dalam mengatasi segala problem yang ada. pendekatan ini merujuk pada Al-Qur'an, Hadist, dan Sunnah yang dituangkan melalui tema pembahasan dalam konseling kelompok seperti: sejarah teladan Nabi dan Rasul melalui cerita motivasi, trening dilarang keras menyakiti orang-orang sesama mukmin.

Pola penyampaiannya adalah pertama konselor membaca ayat dan artinya, kemudian konselor menerangkan dari ayat tersebut dengan bahasa yang mudah dipahami oleh konseli.

\section{d. Sesi IV (penutup)}

Pada sesi penutup yaitu sesi terminasi konseling, sesi ini konselor menyampaikan bahwa kegiatan akan berakhir, membuat kesimpulan langkah-langkah penanggulangan bullying, peserta kelompok menyampaikan pesan dan kesan selama menjalankan dinamika konseling kelompok, dan konselor memotivasi konseli untuk mengimplementasikan hasil konseling dalam kehidupan sehari hari.

3. Tahap Akhir

Proses penilaian akhir dengan menunjukkan hasil yang signifikan, interpretasi dari hasil tersebut adalah dengan melihat perkembangan pada konseli yang cenderung didominasi pola kognitif yang positif melalui pendampingan dan pemantauan dari konselor. Dampak kotribusi yang diberikan diantaranya: pendampingan dan pemantauwan terhadap 
konseli pada masa transisi, pendampingan dalam upaya menumbuhkembangkan dominasi pola prilaku dan pola pikir positif dalam lingkungan sekolah. menjalin kerjasama guru kelas, orang tua konseli sebagai bentuk kontribusi langsung dengan membangun komunikasi positif dalam masa pendampingan, selanjutnya social support yaitu: mengumpulkan konseli pada jam-jam tertentu disertakan memberikan materi-materi ringan seperti nasehat-nasehat, motivasi, berbuat baik, saling menyayangi, melalui intervensi psikososial yang berbasis comunitas, sekaligus pengembangan diri secara kolektif yang dikolaborasikan dengan family support, di mana orang tua yang mempunyai hubungan dekat dengan konseli yang terlibat kasus bullying. Upaya ini sebagai bentuk harapan agar meningkatkan kesadaran anak dalam melakukan kebaikan dan mampu menjaga keseimbangan emosi di lingkungan sekolah SDIT Luqman Al-Hakim Yogyakarta.

Dari hasil, tergambar bahwa konseli pasca konseling kelompok memperoleh cara menemukan pikiran serta mendapatkan kecakapan membuat koping setatement yang positif untuk memperoleh kematangan dalam merespon tindakan bullying melalui upaya memperkecil kecemasan. Hal tersebut dibuktikan dengan adanya hubungan pikiran dan perasaan korban bullying maupun pelaku bullying. Sebagai pelaku, mereka mengemukakan adanya rasa kasih sayang, tolenransi, dan empati dengan cara melihat diri sendiri ketika di perlakukan tidak adil oleh orang lain. Bagi korban adanya rasa percaya diri, harga diri, dan kembalinya motivasi dalam melakukan sesuatu. Secara garis besar, eksperimen prilaku untuk memperkuat keyakinan dalam membentuk prilaku baru pasca konseling kelompok mempunyai cara dan tahapan masing-masing dalam penyesuaiannya.

Pikiran Alternatif Negatif

\begin{tabular}{|c|c|c|}
\hline Situasi & Pikiran (-) & Apa yang saya rasakan? \\
\hline Bullying & $\begin{array}{c}\text { Mereka memperlakukan saya tidak adil, } \\
\text { mereka menyakiti saya }\end{array}$ & $\begin{array}{c}\text { Dendam, marah, geram, jengkel, } \\
\text { rendah diri, takut, bingung, kecce }\end{array}$ \\
\hline
\end{tabular}

\begin{tabular}{|c|c|c|}
\hline Situasi & Pikiran $(+)$ & Apa yang saya rasakan? \\
\hline Bullying & $\begin{array}{c}\text { Mereka menyakiti saya, tetapi saat itu } \\
\text { mereka mengharapkan bantuan saya dan } \\
\text { sekarang tidak lagi }\end{array}$ & Enjoy, kembali ceria dan bahagia \\
\hline
\end{tabular}

Gambar 1. Hubungan Pikiran dan Perasaan (Korban) 
Gambar di atas menjelaskan hubungan pikiran dan perasaan korban bullying. Dalam kondisi mendukung disaat konseli mengalami bullying pikiran alternatif yang dirasakan oleh konseli lebih didominansi pada pikiran alternatif negatif atau irasional. Maka yang terjadi pada konseli adanya perasaan sakit, marah, geram, jengkel, rendah diri, hilangnya motivasi, takut, bingung hingga membuat konseli terpuruk. Pikiran alternatif negatif tersebut sangat menghambat usaha konseli untuk mencapai kestabilan fisik dan psikis. ketika perlakuan diberikan melalui konseling kelompok, pikiran yang sebelumnya negatif ditanggulangi sebagai bentuk pengalihan dengan memasukkan pikiran positif yang lebih produktif. Konselor Muhammad Hermawan menjelaskan ketika konseli sudah mendapat perlakuan dengan adanya konseling kelompok, maka respon konseli mengenai bullying lebih didominasi oleh pikiran alternatif yang produktif. Muhammad Azam (konseli) menjelaskan konseling kelompok membantunya menemukan pikiran alternatif positif dengan memandang bahwa bullying adalah sebuah cobaan yang di dalamnya ada pembelajaran dan hikmah yang didapatkan.

Pikiran Alternatif Negatif

\begin{tabular}{|c|c|c|}
\hline Situasi & Pikiran (-) & Apa yang saya rasakan? \\
\hline Bullying & $\begin{array}{c}\text { Mereka membuat saya marah dan } \\
\text { mendorong saya untuk melakukan } \\
\text { sesuatu }\end{array}$ & $\begin{array}{c}\text { Sakit, marah, geram, jengkel, } \\
\text { bingung, kecewa }\end{array}$ \\
\hline
\end{tabular}

Pikiran Alternatif Positif

\begin{tabular}{|c|c|c|}
\hline Situasi & Pikiran $(+)$ & Apa yang saya rasakan? \\
\hline Bullying & $\begin{array}{c}\text { Ini adalah cobaan bagi saya, mungkin } \\
\text { teguran dan perlakuan yang diberikan } \\
\text { ada baiknya untuk pengembangan } \\
\text { kepribadian saya }\end{array}$ & $\begin{array}{c}\text { Enjoy, kembali ceria dan bahagia } \\
\text { dan upaya untuk meredam aksi } \\
\text { marah. }\end{array}$ \\
\hline
\end{tabular}

Gambar 2. Hubungan Pikiran dan Perasaan (Pelaku)

Gambar di atas menjelaskan hubungan pikiran dan perasaan konseli pelaku bullying. Sebelum pelaku bullying mendapatkan konseling kelompok didominasi pada pikiran alternatif negatif. Maka yang terjadi pada pelaku bullying adalah perasaan sakit hati, marah, geram, jengkel, bingung, kecewa hingga mendorong pelaku untuk bertindak tidak adil terhadap orang lain. Pikiran alternatif negatif tersebut sangat menghambat usaha pelaku 
untuk mencapai kestabilan fisik dan psikis. Setelah mendapatkan intervensi dari konseling kelompok, pikiran negatif ditanggulangi sebagai bentuk pengalihan dengan memasukkan pikiran positif yang lebih produktif. Sehingga bila nantinya pelaku berhadapan dengan situasi yang mendukung (dorongan melakukan bullying) maka respon kognisi pada pelaku lebih cenderung kepada pikiran alternatif yang positif dan produktif. Upaya meminimalisir dorongan negatif tersebut seperti konseli menganggap: teguran adalah sebuah perlakuan untuk menyelamatkannya pada situasi yang merugikan diri sendiri. Dengan demikian perasaan yang di dapatkan tidak lagi menyakitkan hati dan perasaan pelaku sehingga pelaku kembali merasakan ceria, bahagia dan upaya untuk meredam aksi marah.

\section{SIMPULAN}

Berdasarkan analisis serta pembahasan terhadap temuan-temuan di lapangan hasil penelitian yang berkenaan 'Implementasi Konseling Kelompok Dalam Mengatasi Praktik Bullying pada Peserta Didik di SDIT Luqman Al-Hakim Yogyakarta" maka peneliti menyimpulkan sebagai berikut:

1. Implementasi konseling kelompok dikemas dalam empat sesi yaitu: Sesi pertama pembentukan; konselor fokus pada pengembangan informasi dalam pelaksanaan konseling kelompok yang bertujuan agar peserta didik termotivasi dengan agenda yang akan dijalankan. Agenda tersebut diantaranya; penyampaian aturan-aturan, penyampaian kode etik serta pola komunikasi yang akan dibangun. Sesi kedua peralihan; konselor menjelaskan pola interaksi yang efektif, mendengarkan pengalaman yang merupakan bagian dari identifikasi terkait dengan faktor terjadinya bullying. Sesi ketiga kegiatan; berisi empat model materi diantaranya: (a) model konseling kelompok berbasis pendekatan persuasif. Dalam pendekatan ini konselor berfokus pada aspek kognitif, sikap dan prilaku. Tujuan dari pendekatan tersebut agar peserta didik bertindak sesuai dengan harapan konselor. (b) model konseling kelompok berbasis pendekatan klasikal. Dilaksanakan melalui interaksi edukatif, menggunakan metode ceramah, diskusi, tanya jawab, LCD, media film, hand out, dan terjadual. Topik yang diangkat antara lain: cerita motivasi, tugas, tanggung jawab, kasih sayang serta trening motivasi. Dengan durasi waktu hanya 30 menit sampai 1 jam. Tujuannya agar peserta didik menemukan wawasan, mendapatkan pengalaman baru, memancing motivasi, percaya diri, serta kasih sayang antar sesama. (c) model konseling kelompok berbasis pendekatan sosial. Tujuan pola interaksi positif untuk tercipta umpan balik antara konselor dengan peserta didik hingga terjadinya transferensi di mana peserta 
didik melimpahkan pengalaman masa lalunya kepada konselor dan konselor memperhatikan apa yang disampaikan oleh peserta didik. (d) model pendekatan Islami. Materi yang disampaikan berupa cerita Islami baik dengan pola diskusi, permainan, relaksasi, rekreasi, resiliensi dan sebagainya. Tujuannya agar peserta memiliki aqidah, Islam, Iman, Taqwa kepada Allah SWT, memiliki wawasan berpikir luas kritis, logis, sistematis dan kreatif, cermat serta cerdik dalam mengatasi segala problem yang dihadapi. Sesi keempat penutup. Pada sesi ini konselor menyampaikan terminasi konseling, membuat kesimpulan berkaitan dengan langkah-langkah penanggulangan bullying, peserta didik menyampaikan pesan dan kesan selama menjalankan dinamika konseling kelompok dan ditutup dengan membacakan doa.

Secara umum implementasi konseling kelompok di SDIT Al-Hakim sangat efektif di mana konselor mampu mengembalikan hubungan pikiran dan perasaan yang negatif peserta didik kepada hubungan pikiran dan perasaan yang positif sehingga ketika peserta didik berhadapan dengan permasalahan, peserta didik sudah mampu menemukan alternatifalternatif positif dalam pencapaian jalan keluar.

2. Kendala yang dihadapi diantaranya; pertama kendala internal konselor yaitu kemampuan pedagogik konselor (bersifat mendidik) seperti keterbatasan konselor memberikan bimbingan belajar sesuai dengan tema, keterbatasan pemahaman karakteristik kepribadian peserta didik seperti status sosial, ras, etnis, dan usia. Kedua kendala internal peserta didik seperti ketidakterbukaan, luapan emosi peserta didik secara tiba-tiba yang memungkinkan dampak negatif dan positif. (1) menghambat jalannya konseling kelompok (dampak emosi negatif), (2) tidak menghambat jalannya konseling kelompok (dampak emosi positif). Emosi yang menghambat jalannya konseling kelompok seperti marah, menangis dan sebagainya. sedangkan emosi yang tidak menghambat jalannya konseling kelompok seperti empati, eksplorasi dan sebagainya.

\section{REFERENSI}

Afriana, Yusmansyah, Utaminingsih, Upaya Mengurangi Perilaku Bullying Di sekolah Dengan Menggunakan Layanan Konseling Kelompok. Jurnal Konseling.

Deni Febriani. (2011). Bimbingan Konseling, Yogyakarta, Teras.

Hayati, I., \& Sujadi, E. (2018). Perbedaan Keterampilan Belajar Antara Siswa IPA dan IPS. Tarbawi : Jurnal Imu Pendidikan, 14(1), 1-10. doi:10.32939/tarbawi.v14i1.250 
Juntika Achmad. (2006). Strategi Layanan Bimbingan Dan Konseling, Bandung, Regika Aditama.

M Jamal. (2016). Fenomena Kekerasan Di Sekolah, Yogyakarta, Pustaka Pelajar.

Moh. Nazir. (2003). Metode Penelitian, Jakarta, Ghalia Indonesia.

Namora Lumonga Lubis. (2011). Memahami Dasar-Dasar Konseling, Jakarta, Kencana.

Nova Ardy Wiyani, School Bullying, Yogyakarta, Ar-Ruzz Media.

Peraturan Mentri Pendidikan Nasional RI No, 41 Tahun. (2007). Tentang Standar Proses Satuan Pendidikan Dasar Dan Menengah, Jakarta: Bandan Standar Nasional Pendidikan.

Ponny Retno. (2008). Astuti, Meredam Bullying, Jakarta, Grasindo.

Prayitno dan Amti. (2014). Dasar-Dasar Bimbingan dan Konseling, Jakarta, Rineka Cipta.

Sugiyono. (2013). Memahami Penelitian Kualitatif, Bandung, Alfabeta.

Sujadi, E. (2017). Penerapan Pendidikan Karakter Cerdas Format Kelompok Untuk Meningkatkan Nilai Kejujuran Mahasiswa Bimbingan Konseling Islam (BKI) Institut Agama Islam Negeri (IAIN) Kerinci. Tarbawi : Jurnal Ilmu Pendidikan, 13(1), 97-108

Sujadi, E., \& Wahab, M. (2018). Strategi Coping Korban Bullying. Tarbawi : Jurnal Ilmu Pendidikan, 13(2), 21-32. 